\title{
Dynamics and interaction of organic carbon, turbidity and bacteria in a karst aquifer system
}

\author{
Michiel Pronk • Nico Goldscheider · Jakob Zopfi
}

\begin{abstract}
The dynamics of organic carbon (OC), turbidity, faecal indicator bacteria and physicochemical parameters was studied in a karst system near Yverdon, Switzerland. Online measurements and sampling were done at a swallow hole draining an agricultural surface (the input), and two groups of springs (the outputs) that often show bacterial contamination. A fluorescent tracer that was injected into the swallow hole during low-flow conditions first arrived at the springs 10-12 days after injection; the total recovery rate was $29 \%$. Previous tracer tests during high-flow conditions gave shorter travel times. After a major rainfall event, a primary turbidity peak was observed at the springs. It coincides with the rising limb of the hydrograph, indicating remobilisation of autochthonous particles from the aquifer. A secondary turbidity peak occurs several days later, suggesting the arrival of allochthonous particles from the swallow hole. Wider peaks of OC and bacteria were observed simultaneously. Applying methods from molecular microbiology (PCR-DGGE) allowed characterisation of the bacterial communities at the swallow hole and the springs. The results demonstrate that the swallow hole is an important source of groundwater contamination, while its contribution to aquifer recharge is insignificant. OC appears to be a better indicator for bacterial contamination than turbidity.
\end{abstract}

Résumé La dynamique du carbone organique, de la turbidité, des bactéries indicatrices de contamination fécale et d'autres paramètres physico-chimiques a été étudiée

Received: 30 April 2004 / Accepted: 1 March 2005

Published online: 11 June 2005

(C) Springer-Verlag 2005

M. Pronk · N. Goldscheider $(\bowtie)$

Centre of Hydrogeology, University of Neuchâtel,

Rue Emile-Argand 11,

2007 Neuchâtel, Switzerland

e-mail: nico.goldscheider@unine.ch

Tel.: +41-32-718-2645

Fax: +41-32-718-2603

J. Zopfi

Laboratory of Microbiology, University of Neuchâtel,

Rue Emile-Argand 9,

2007 Neuchâtel, Switzerland dans un système karstique proche de la ville d'Yverdonles-Bains, Suisse. Des mesures en continu ainsi que des échantillonnages ont été effectués à une perte drainant une zone agricole (input), et à deux groupes sourciers (output) qui montrent fréquemment une contamination bactérienne. En période d'étiage, un essai de traçage à l'uranine a été réalisé depuis la perte. Le traceur est apparu aux sources 10-12 jours après l'injection; la masse de restitution totale a été de $29 \%$. Des essais précédents, réalisés en hautes eaux, ont montré des temps de transit plus court. Suite à un événement pluvieux important, un pic de turbidité primaire, synchrone avec l'augmentation du débit, est observé aux sources, indiquant une re-mobilisation des sédiments autochtones de l'aquifère. Un pic de turbidité secondaire apparaît quelques jours plus tard aux sources, suggérant l'arrivée de matériel allochtone de la perte. Cette dernière est accompagnée de pics plus larges de carbone organique et des bactéries indicatrices de contamination fécale. La microbiologie moléculaire (PCR-DGGE) a permis la caractérisation des communautés bactériennes de la perte et des sources. Ces résultats démontrent l'importante influence de la perte sur la qualité de l'eau souterraine, alors que sa contribution au débit du système est négligeable. Le carbone organique semble être un meilleur indicateur de la présence de contamination bactérienne que la turbidité.

Resumen Se ha estudiado la dinámica del carbono orgánico, turbiedad, una bacteria indicadora de fecales, y parámetros fisicoquímicos en un sistema kárstico cerca de Yverdon, Suiza. Se realizaron mediciones en línea y muestreo en un sumidero que drena una superficie agrícola (la entrada), y dos grupos de manantiales (las salidas) que frecuentemente muestran contaminación bacterial. Un trazador fluorescente que se inyectó en el sumidero durante condiciones de flujo bajo arribó en los manantiales por vez primera 10-12 días después de que fue inyectado; el ritmo total de recuperación fue de $29 \%$. Las pruebas de trazadores realizadas con anterioridad bajo condiciones de flujo alto aportaron tiempos de viaje más cortos. Después de una tormenta fuerte se observó un pico de turbiedad primario en los manantiales. El pico coincide con el limbo ascendente del hidrograma indicando remobilización de partículas alóctonas provenientes del acuífero. Un pico de turbiedad secundario ocurre varios días más tarde sugiriendo el arribo de partículas alóctonas provenientes del 
sumidero. Se observaron simultáneamente picos más amplios de carbono orgánico y bacteria. La aplicación de métodos de microbiología molecular (PCR-DGGE) permitieron caracterizar las comunidades de bacteria en el sumidero y los manantiales. Los resultados demuestran que el sumidero es una fuente importante de contaminación de aguas subterráneas mientras que su contribución a la recarga del acuífero es insignificante. El carbono orgánico parece ser un mejor indicador de contaminación bacterial que la turbiedad.

Keywords Karst aquifer - Tracer test - Organic carbon . Turbidity $\cdot$ Microbial community

\section{Introduction}

Pathogenic microorganisms are among the most frequent and problematic contaminants in groundwater from karst aquifers (Auckenthaler and Huggenberger 2003). Although most microorganisms are harmless, the presence of faecal bacteria (e.g. Escherichia coli) in groundwater indicates the possible presence of pathogenic bacteria, protozoans and viruses (Personne et al. 1998). In rural karst areas, faecal bacteria often originate from agricultural activities, like cattle pasturing and the application of manure (Drew and Hötzl 1999; Boyer and Pasquarell 1999). Karst aquifers are particularly vulnerable to contamination (Zwahlen 2004). In recharge periods, bacteria and other contaminants from the land surface are washed into the aquifer; either diffusely by infiltration and percolation through the soil and unsaturated zone, or concentrated via swallow holes. Inside the aquifer, there is rapid contaminant transport in the conduit network. Karst aquifer systems are thus characterised by fast and strong reactions to hydrologic events, resulting in sudden variations of spring discharge and physical, chemical, isotopic and microbiological water composition (Ford and Williams 1989; Katz et al. 1998).

Monitoring microbial water quality relies on sterile water sampling and subsequent laboratory analyses (Mikell et al. 1996). The sampling intervals and the lags between sampling and analyses are often too widely spaced to detect the time of arrival of bacterial contamination in karst spring water. In contrast, various hydrological and physicochemical properties can be measured online. If correlation between these easy-to-measure parameters and microbial water quality were established, they could be used as indicators for the presence of microbial pathogens. Several approaches were made to do so.

Some authors suggest that turbidity indicates the presence of microbial pathogens (Nebbache et al. 1997; Ryan and Meiman 1996), and that bacteria are transported attached on suspended particles (Mahler et al. 2000). However, there are a wide range of colloids and particles in groundwater, which have different origins and properties (Atteia 1998; Atteia and Kozel 1997; Lacroix et al. 2000). Pathogenic bacteria generally come from outside the aquifer (allochthonous), while turbidity may either be allochthonous or result from remobilisation of sediments inside the aquifer (autochthonous) (Amraoui et al. 2003; Bouchaou et al. 2002). Mineral particles are prone to sedimentation, while planktonic bacteria have little tendency to settle down (Massei et al. 2003). Turbidity is thus not always a reliable indicator for bacteria.

Other authors propose using spring discharge as an indicator for microbial pathogens, because microbial contamination events often coincide with flood events, not only in karst systems (Auckenthaler et al. 2002). However, there is not always correlation between discharge and bacteria content: On the one hand, higher flow rates reinforce bacterial transport; on the other hand, higher flow rates may dilute contaminated water.

Karst spring waters often show variable contents of organic carbon (OC), which may be present as particulate (POC) or dissolved organic carbon (DOC); the sum of both is the total organic carbon (TOC) (Batiot et al. 2003; Emblanch et al. 1998). In natural waters, DOC often makes up about $90 \%$ of the TOC (Batiot 2003; Thurman 1985). OC in groundwater results from incomplete degradation of organic matter in the soil. During recharge periods, it is washed into the aquifer. Chemoorganoheterotrophic bacteria in the aquifer depend on $\mathrm{OC}$ as carbon and energy sources (Chapelle 2001). OC thus suffers microbial degradation, although a significant fraction of it may be recalcitrant (Alberic and Lepiller 1998). As both faecal bacteria and OC originate from the land surface and soil (allochthonous), OC appears to be a promising indicator for the presence of faecal bacteria in the groundwater.

The main objective of the study presented in this paper was to obtain a better understanding of the dynamics and complex interaction between organic carbon, turbidity, faecal indicator bacteria, spring discharge and different physical-chemical parameters in karst hydrogeological systems. The practical goal was to identify easy-to-measure parameters or combinations of parameters that indicate the possible presence of microbial pathogens.

Most microorganisms in groundwater are viable but non-cultivable cells (Byrd et al. 1991; Szewzyk et al. 2000). Enumeration of faecal bacteria on culture media thus provides an incomplete picture of the microbial communities. Aquifers include habitats for a wide range of organisms, some of which are crucial for geochemical processes. Aquifers are thus increasingly considered as ecosystems (Danielopol et al. 2003; Simon et al. 2001). The Swiss Water Protection Ordinance demands that the biocenoses in groundwater should be in a natural state, adapted to the habitat, and typical for non-polluted water (GSchV 1998). This paper presents an attempt to characterise microbial communities in karst groundwater using methods from molecular microbiology, and to link these observations to the dynamics of other parameters.

A karst hydrogeological system near the city of Yverdonles-Bains in Switzerland was selected as a test site, because it allows observation of the input, transport and output of organic carbon, turbidity and bacteria: The concentrated input into the system was measured at a swallow hole (Feurtille) draining agricultural land; the transport inside the system was studied by means of a tracer test; the output 
Fig. 1 Location, geological map (after Jordi 1994) and cross-section of the test site. The Feurtille swallow hole (F), the Moulinet spring (M) and the Cossaux spring (C) are located near a major fault line, at the contact between the Jurassic-Cretaceous karst aquifer system and overlying Tertiary-Quaternary formations

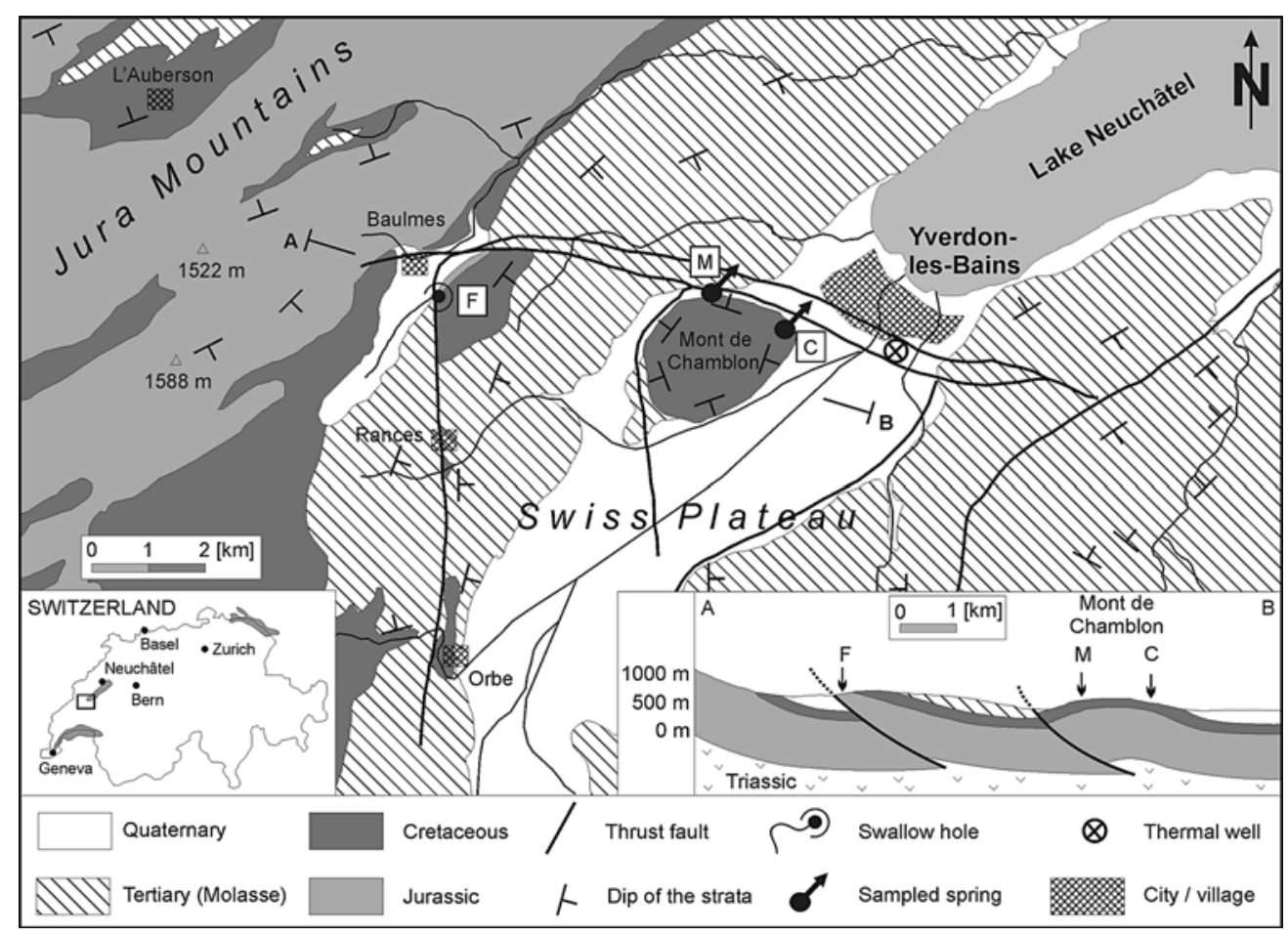

was observed at two karst springs. The Cossaux spring is used as a drinking water source for the city but sometimes has microbial water quality problems. The Moulinet spring is not used as it is often contaminated with bacteria.

\section{Description of the test site}

The test site (Fig. 1) is located between two major landscape units: the Swiss Plateau and the Jura Mountains. Lake Neuchâtel forms the regional hydrologic base level (429 m). The Jura Mountains reach altitudes of more than $1500 \mathrm{~m}$ near the test site. Mean annual precipitation ranges between $1000 \mathrm{~mm}$ in the Plateau and $1600 \mathrm{~mm}$ in the Mountains.

This contrast in landscape reflects the contrast between two major geological units: the Folded Jura Mountains and the Molasse Basin. The Jura Mountains consist of Jurassic and Cretaceous limestone and marl. The strata were folded and thrusted at the end of the alpine orogenesis in the Mio- and Pliocene. The fold axes strike SW-NE. Towards the SE, the strata plunge under the Molasse Basin, the northern foreland basin of the Alps, which formed during Oligocene and Miocene. In the study area, the Molasse is mainly composed of marl and sandstone. Glacial and postglacial deposits cover wide areas of the Swiss Plateau. Two series of transpressive faults structure the region of Yverdon: N-S trending left-lateral faults and E-W trending right-lateral faults. The complex arrangement of folds and faults raised two hills, exposing in this way Jurassic and Cretaceous carbonate rocks within the Molasse zone (Muralt et al. 1997; Sommaruga 1996, 1999).

Upper Jurassic (Malm) limestones with a total thickness of $400 \mathrm{~m}$ form the main regional karst aquifer. The lime- stones from the Valanginian (30-50 m thick) and Hauterivian (30-60 m thick) are also karstified. These aquifers are separated by thin marl aquicludes. The SE slope of the Jura Mountains near the village of Baulmes is the most important autogenic recharge area of the test site (Muralt 1999). Large parts of this zone are forested and recharge mainly occurs diffusely through the soil. There are consequently few contamination problems, resulting from local cattle pasture.

Further to the SE, on the Swiss Plateau, Molasse marls and sandstones confine the karst aquifer systems. The above mentioned two hills act as hydrogeological windows and allow for water exchange between the land surface and the karst aquifer system.

The Feurtille swallow hole is located at an altitude of $600 \mathrm{~m}$ at the western of these two hills, at the contact between the Molasse (covered with Quaternary sediments) and the Malm karst aquifer (Fig. 1). The stream sinking into this swallow hole drains an agricultural area and is frequently contaminated with nitrates and bacteria; its flow rate ranges between 0 and $200 \mathrm{~L} / \mathrm{s}$. Recharge via the swallow hole can be classified as allogenic point recharge.

The Moulinet and Cossaux karst springs are located at an altitude of $450 \mathrm{~m}$ at the eastern hill (Mont de Chamblon) and discharge from Valanginian and Hauterivian limestone. Detailed hydrochemical and isotopic investigations showed that the spring water consists of four different components: (A) thermal groundwater from several hundred meters depth, (B) cold and slightly contaminated groundwater from the Malm karst aquifer, (C) cold and frequently contaminated water from the Feurtille swallow hole, and (D) cold local groundwater from the Mont de Chamblon (Muralt 1999, Muralt et al. 1997). 
The Moulinet spring consists of eight individual outlets: $6 \mathrm{~A}, \mathrm{~B}$, and $7 \mathrm{~A}-\mathrm{F}$. The total discharge of this group of springs varies between $20 \mathrm{~L} / \mathrm{s}$ and about $1000 \mathrm{~L} / \mathrm{s}$. Springs $6 \mathrm{~A}, \mathrm{~B}$ and $7 \mathrm{~B}$ are permanent, while the others sometimes run dry. The two captured springs $6 \mathrm{~A}$ and $\mathrm{B}$ were used for the drinking water supply of Yverdon during the first half of the 20th century, but then abandoned because of frequent microbial contamination.

The Cossaux spring is captured by means of eight inclined drillings and contributes to the drinking water supply of Yverdon. The water quality is generally good although nitrate and bacteria sometimes cause problems. The total discharge ranges between 28 and $205 \mathrm{~L} / \mathrm{s}$ (unpublished reports by Schardt 1910, 1920; Looser 1990, Blanc 1995).

However, despite of the same origins for the waters feeding the two groups of springs, they show significant differences in their biological, chemical and physical compositions. These differences are clearly expressed by the water temperature, 9.5 to $12.5^{\circ} \mathrm{C}$ at the Moulinet springs and 13.0 to $14.5^{\circ} \mathrm{C}$ at the Cossaux spring. This indicates a higher contribution of the thermal groundwater (component A) at the Cossaux spring (Muralt 1999).

\section{Tracer test}

\section{Overview, objectives and experimental design}

Three previous tracer tests with uranine proved the underground connection between the swallow hole and the two springs (unpublished reports by Schardt 1910, 1920; Looser 1990). These tracer tests gave transit times ranging between two days during high flow and 12 days during low flow conditions. Detailed breakthrough curves were not recorded, and so it was not possible to obtain quantitative information on the flow system.

In order to better characterise groundwater flow and contaminant transport from the Feurtille swallow hole to the springs, a dye-tracing test was carried out at the 1 st of September 2003 during low-flow conditions. Uranine (sodium-fluorescein) was selected as a tracer because of its favourable properties (Käss 1998). $1 \mathrm{~kg}$ of this fluorescent dye was dissolved into $10 \mathrm{~L}$ of water and directly injected into the swallow hole. The flow rate at the swallow hole was $1 \mathrm{~L} / \mathrm{s}$.

Two flow-through field fluorometers (GGUN-FL30, Schnegg and Costa 2003) were installed at the Moulinet $6 \mathrm{~A}$ and Cossaux springs in order to measure quasicontinuously (every $4 \mathrm{~min}$ ) the dye concentration. Moulinet 6B spring was sampled automatically every three hours; manual samples were daily taken at spring $7 \mathrm{~B}$. The other outlets of this group of springs were dry during the weeks following injection but were sampled after a storm rainfall event in October. Occasional samples were taken at another very small spring (Grange-Décoppet) $1 \mathrm{~km} \mathrm{SW}$ of the Moulinet springs. The water samples were analysed in the CHYN laboratory using a spectral fluorimeter (PERKIN ELMER LS $50 \mathrm{~B}$ ) in the synchronous scan mode.

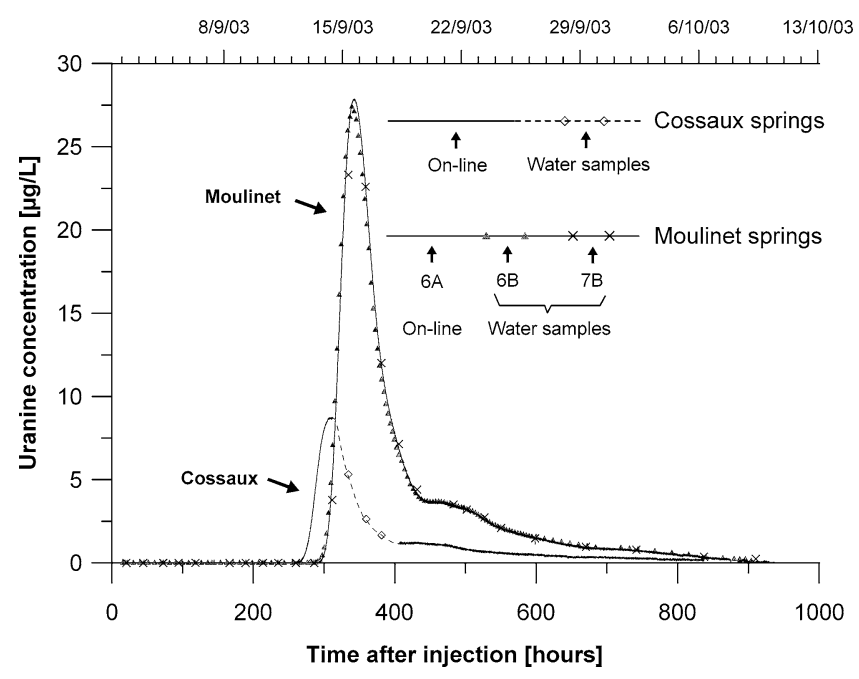

Fig. 2 Uranine breakthrough curves at the Moulinet springs (6A, B and $7 \mathrm{~B}$ ) and the Cossaux spring. Surprisingly the tracer first arrived at the Cossaux spring, although the Moulinet springs are closer to the injection point. The curves have a similar form but concentrations at the Moulinet springs are three times higher than at the Cossaux spring. This observation indicates that the Cossaux spring receives additional inflow from another type of groundwater that is free of uranine

\section{Results}

The distance from the swallow hole to the Moulinet spring is $4.8 \mathrm{~km}$, while the distance to the Cossaux spring is $6.3 \mathrm{~km}$. Surprisingly the tracer first arrived at the Cossaux spring $260 \mathrm{~h}(11 \mathrm{~d})$ after the injection and reached a maximum concentration of $8.7 \mu \mathrm{g} / \mathrm{l}$ after $312 \mathrm{~h}(13 \mathrm{~d})$. At the Moulinet springs, the tracer first arrived after $292 \mathrm{~h}(12 \mathrm{~d})$, the maximum concentration of $27.8 \mu \mathrm{g} / \mathrm{l}$ was measured $343 \mathrm{~h}(14 \mathrm{~d})$ after the injection (Fig. 2). Sampling strategies and analytical methods during the previous tracer tests (Schardt 1910, 1920; Looser 1990, unpublished reports) were not appropriate to observe this difference in travel time.

The breakthrough curves at the three permanent Moulinet springs (6A, B, 7B) are almost identical, proving that these springs are outlets of the same flow system. After heavy rainfall events at the beginning of October, the non-permanent springs (7A, C-F) started to discharge again. Identical uranine concentrations were subsequently measured at all eight springs of this group, proving that they are outlets of the same system. Uranine was also detected in three samples taken at the small Grange-Décoppet spring.

The shape of the breakthrough curves of the Moulinet and Cossaux springs are remarkably similar. The time shift between the curves is $33 \mathrm{~h}$, and the tracer concentrations at the Moulinet springs are three times higher than at the Cossaux spring. This observation suggests that the Cossaux spring receives additional contribution from another type of groundwater that is free of uranine, causing dilution of the concentrations. The different concentrations cannot be attributed to dispersion, double-porosity effects, adsorption, degradation or other processes, as these would change the shape of the breakthrough curve. 
The maximum linear groundwater flow velocities (calculated from the linear distance and the time of first arrival) are $16 \mathrm{~m} / \mathrm{h}$ for the Moulinet spring and $24 \mathrm{~m} / \mathrm{h}$ for the Cossaux spring. The dominant linear flow velocities are 14 and $20 \mathrm{~m} / \mathrm{h}$ respectively. However, these values do not represent the real flow velocities in the conduit system.

After the first peak of the breakthrough curves, secondary uranine peaks were observed at the Cossaux $(400-500 \mathrm{~h}$ after injection) and Moulinet springs (450-550 h after injection). This can be explained by remobilisation of uranine from the unsaturated zone near the injection point during the rainfall events of the 8th of September (Figs. 2 and 4).

The tracer recovery rates were calculated based on the concentration-discharge-time data series. $12.2 \%$ (122 g) of the tracer was recovered at the Cossaux spring. The recovery rates at the Moulinet springs $6 \mathrm{~A}, \mathrm{~B}$ and $7 \mathrm{~B}$ are $3.7,8.7$ and $4.4 \%$ respectively. The recovery rates at the other springs of this group are insignificant, because they were dry during the essential phase of the sampling period. The total tracer recovery at the Moulinet springs is thus $16.8 \%(168 \mathrm{~g})$ and the total tracer recovery at all springs is $29 \%(290 \mathrm{~g})$.

These results demonstrate that contaminated water sinking into the swallow hole may have a major impact on the spring water quality, while the contribution to the water quantity (spring discharge) is insignificant during low-flow conditions.

\section{Quantification of flow rates inside the karst aquifer system}

The tracer test results made it possible to improve the existing conceptual model of the karst aquifer system (Muralt 1999) and to quantify the groundwater flow rates during low-flow conditions. The model is based on the following observations and assumptions:

1. The tracer test proved a connection between the swallow hole and the springs.

2. Geological and hydrological observations, as well as water temperature, chemical and isotopic data suggest that the two springs also receive inflow from a deep thermal aquifer (A) and from the Malm karst aquifer (B). Local groundwater from the Mont de Chamblon (D) does not contribute significantly during dry periods (Muralt 1999).

3. The tracer breakthrough curves at the two springs have a similar shape, but the concentrations at the Moulinet spring are three times higher than at the Cossaux spring. This suggests that the Cossaux spring receives additional inflow from groundwater that is free of uranine. Water temperature, chemical, isotopic and microbiological data further confirm this assumption.

4. Only $29 \%$ of the uranine was recovered at the springs. In a conduit system, uranine behaves nearly as a conservative tracer, i.e. there is no significant adsorption or degradation loss (Käss 1998). Some tracer might get lost due to conduit-matrix-interaction (double porosity effect). However, during low-flow periods, the conduits drain the matrix and it is unlikely that an important part of the tracer will be stored in the rock matrix (Cornaton and Perrochet 2002). The proposed model thus assumes that most of the tracer that was not recovered at the springs flowed further downgradient; either towards the thermal water wells of Yverdon, which are located on the same fault line as the swallow hole and the springs, or toward Lake Neuchâtel, the regional hydrologic base level.

On this basis, it was possible to design a conceptual model showing the most important underground flow paths (Fig. 3). The model represents the simplest possible solution; the real system is almost certainly much more complicated. The flow rates inside the system can now be determined based on two types of equations: water balance equations, and mass balance equations for uranine (Atkinson et al. 1973; Goldscheider 2002). The calculated flow rates only apply to the hydrologic conditions during the tracer test. According to this calculation, the water and tracer sinking into the swallow hole mixes with $114 \mathrm{~L} / \mathrm{s}$ of groundwater in the karst aquifer. This flow splits up into three pathways: $19 \mathrm{~L} / \mathrm{s}$ go to the Moulinet spring, $14 \mathrm{~L} / \mathrm{s}$ flow to the Cossaux spring, and $81 \mathrm{~L} / \mathrm{s}$ remain in the aquifer. The Cossaux spring receives an additional inflow of $29 \mathrm{~L} / \mathrm{s}$ from a deeper part of the aquifer system, which dilutes the uranine concentrations. However, a small part of the tracer loss might be attributed to double-porosity effects or other processes (see above); the long tail of the tracer breakthrough curve supports this assumption. The true flow rates inside the aquifer might thus be $<114 \mathrm{~L} / \mathrm{s}$ upgradient and $<81 \mathrm{~L} / \mathrm{s}$ downgradient from the springs.

The flow rates and flow velocities are expected to change significantly depending on the hydrologic conditions. Future tracer tests will allow to further improve the proposed model, and to quantify flow rates during average and highflow conditions.

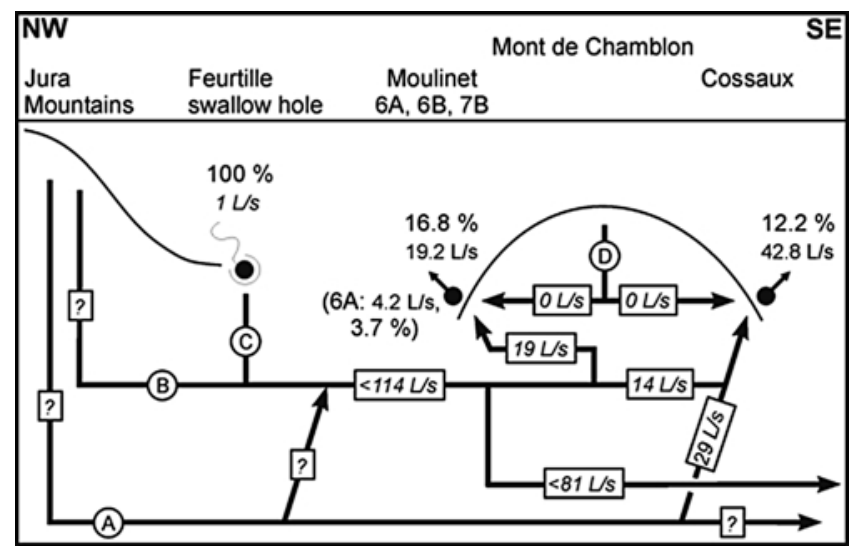

Fig. 3 Simplified conceptual model of the karst system. The groundwater flow rates were calculated using water balance equations and uranine mass balance equations. The values only apply for the hydrologic situation during the tracer test (low-flow). The letters represent the four different water components described previously: (A) deep and thermal groundwater, $(\mathbf{B})$ cold groundwater from the Malm karst aquifer, $(\mathbf{C})$ cold water from the swallow hole, and (D) cold local groundwater from the Mont de Chamblon. The calculations show that the Cossaux spring receives additional inflow from a deeper zone of the aquifer system 


\section{Dynamics of natural parameters}

\section{Monitoring programme and methods}

The observation of natural hydrologic, physical, chemical and microbial parameters focused on two sampling sites: the Feurtille swallow hole (input) and the Moulinet 6A spring (output). As the tracer test described on the previous pages allowed for characterisation of the transport between these two points, it was possible to link the observed dynamics of natural parameters at the spring with the dynamics of these parameters at the swallow hole.

At the swallow hole, the following parameters were measured continuously: discharge, water temperature, TOC and turbidity. Electrical conductivity and faecal indicator bacteria (E. coli, enterococci, coliforms and mesophilic aerobic bacteria) were sampled occasionally.

The monitoring programme at the Moulinet 6A spring was more detailed. It included continuous recording of discharge, temperature, electrical conductivity, DOC and turbidity, as well as water sampling and analyses for nitrate and faecal indicator bacteria. The physical, chemical and microbial water quality at the other springs was measured occasionally.

The discharge rates were measured by means of rectangular weirs and pressure probes. At the Feurtille swallow hole, TOC and turbidity were detected using the flow-through field fluorimeter GGUN-FL30 (Schnegg and Costa 2003), the same instrument that was used to measure uranine. It measures turbidity by the diffusion of light $(660 \mathrm{~nm})$ at an angle of $90^{\circ}$, and TOC by means of UV fluorescence $(370 \mathrm{~nm})$. At the Moulinet $6 \mathrm{~A}$ spring, turbidity was measured by the diffusion of light $(880 \mathrm{~nm})$ at an angle of $90^{\circ}$ using a turbidimeter (SIGRIST WTM 500). DOC was measured by means of UV light absorption (254 nm) combined with a filtration unit $(0.45 \mu \mathrm{m})$ using a photometer (SIGRIST CA100 UV254). Previous laboratory studies showed the reliability of these methods and allowed cross-calibration of the measurement instruments with field samples (Drogue 2003, unpublished report). Bacteria were analysed using cultivation techniques, i.e. heterotrophic plate count (Chapelle 2001).

Precipitation data from three stations were considered in order to interpret the observed dynamics: Yverdon-lesBains (altitude: $433 \mathrm{~m}$, near the springs), Baulmes (642 m, near the swallow hole) and Auberson (1110 m, in the Jura Mountains, the main recharge area of the aquifer).

\section{Dynamics during low-flow conditions}

Summer 2003 was amongst the driest and warmest ever recorded in Switzerland. It was thus possible to observe the behaviour of the karst aquifer system during extreme low flow conditions (Fig. 4). Some precipitation events occurred during this period, the most important on the 27th of July, when $46 \mathrm{~mm}$ of rainfall was measured in Baulmes, near the swallow hole.

The discharge rate at the swallow hole subsequently increased from 1 to $20 \mathrm{~L} / \mathrm{s}$. In August and September, the swallow hole was frequently dry but always reacted rapidly on rainfall events. High contents of turbidity (up to 350 NTU) and TOC (up to $150 \mathrm{mg} / \mathrm{l}$ ) were measured at the swallow hole during these events. All water samples taken at the swallow hole showed very high contents of faecal indicator bacteria. The highest contents were measured during a rainfall event on the 8th of September: 4970 E. coli, 6800 enterococci, 419000 coliforms and 3550000 mesophilic aerobic bacteria (m.a.b.) were found in $100 \mathrm{ml}$. Water temperature at the swallow hole showed daily variations of about $10^{\circ} \mathrm{C}$.

The Moulinet springs showed little variation: the discharge of spring $6 \mathrm{~A}$ was constantly low, about $4.2 \mathrm{~L} / \mathrm{s}$, the discharge rates of $6 \mathrm{~B}$ and $7 \mathrm{~B}$ steadily decreased, 7A and $7 \mathrm{~B}-\mathrm{F}$ were permanently dry. The spring water temperature steadily increased from $11.1^{\circ} \mathrm{C}$ at the end of July to $11.6^{\circ} \mathrm{C}$ at the end of September. As described previously, the spring water is fed by four different components, one of which is thermal groundwater (Muralt et al. 1997). The observed behaviour can thus be explained by a decrease of the cold components, while the warm and deep component remains constant. The DOC concentration at the Moulinet springs remained stable and low at about $0.2 \mathrm{mg} / \mathrm{l}$ during the entire low-flow period.

Electrical conductivity and turbidity showed small but interesting variations after the storm rainfall event of the 27th of July (Fig. 4A). During the first 8 days, conductivity and turbidity remained stable at $440 \mu \mathrm{S} / \mathrm{cm}$ and 0.3 NTU respectively. Conductivity then started to increase and reached a maximum of $446 \mu \mathrm{s} / \mathrm{cm} 9$ days after the rainfall event. The beginning of the decrease in conductivity coincides with the beginning of turbidity increase, and the turbidity maximum ( $0.5 \mathrm{NTU})$ coincides with the conductivity minimum $(435 \mu \mathrm{s} / \mathrm{cm}) 12$ days after the rainfall event. The lag between the rainfall and the coupled turbidity maximum and conductivity minimum corresponds to the lag between the tracer injection into the swallow hole and the tracer arrival at the Moulinet spring, as previously described and shown in Fig. 2. The observed dynamics of turbidity and conductivity at the Moulinet spring thus strongly suggests the arrival of turbid and lowly mineralised water from the swallow hole (allochthonous turbidity). Increased contents of faecal bacteria were measured at springs $6 \mathrm{~A}, \mathrm{~B}$ and $7 \mathrm{~B}$ during this turbidity event, suggesting that the bacteria also originate from the swallow hole.

During the tracer test in September, significant variations of electrical conductivity occurred, while the other parameters remained stable. There is an interesting connection between rainfall, the uranine breakthrough curve and conductivity: As described previously, a secondary uranine peak occurred 450-550 h after the injection due to the remobilisation of uranine from the unsaturated zone near the swallow hole during a rainfall event on the 8th of September. This small tracer peak coincides with a minimum of electrical conductivity, which may indicate the arrival of freshly infiltrated water from the same swallow hole (Fig. 4B). 
Fig. 4 Dynamics of natural parameters during low-flow conditions at the Moulinet 6A spring (below) and the Feurtille swallow hole (above). The variations of turbidity and electrical conductivity (A) are due to the storm rainfall on the 27 th of July. The decrease of conductivity at the end of September coincides with a small secondary uranine peak (B)

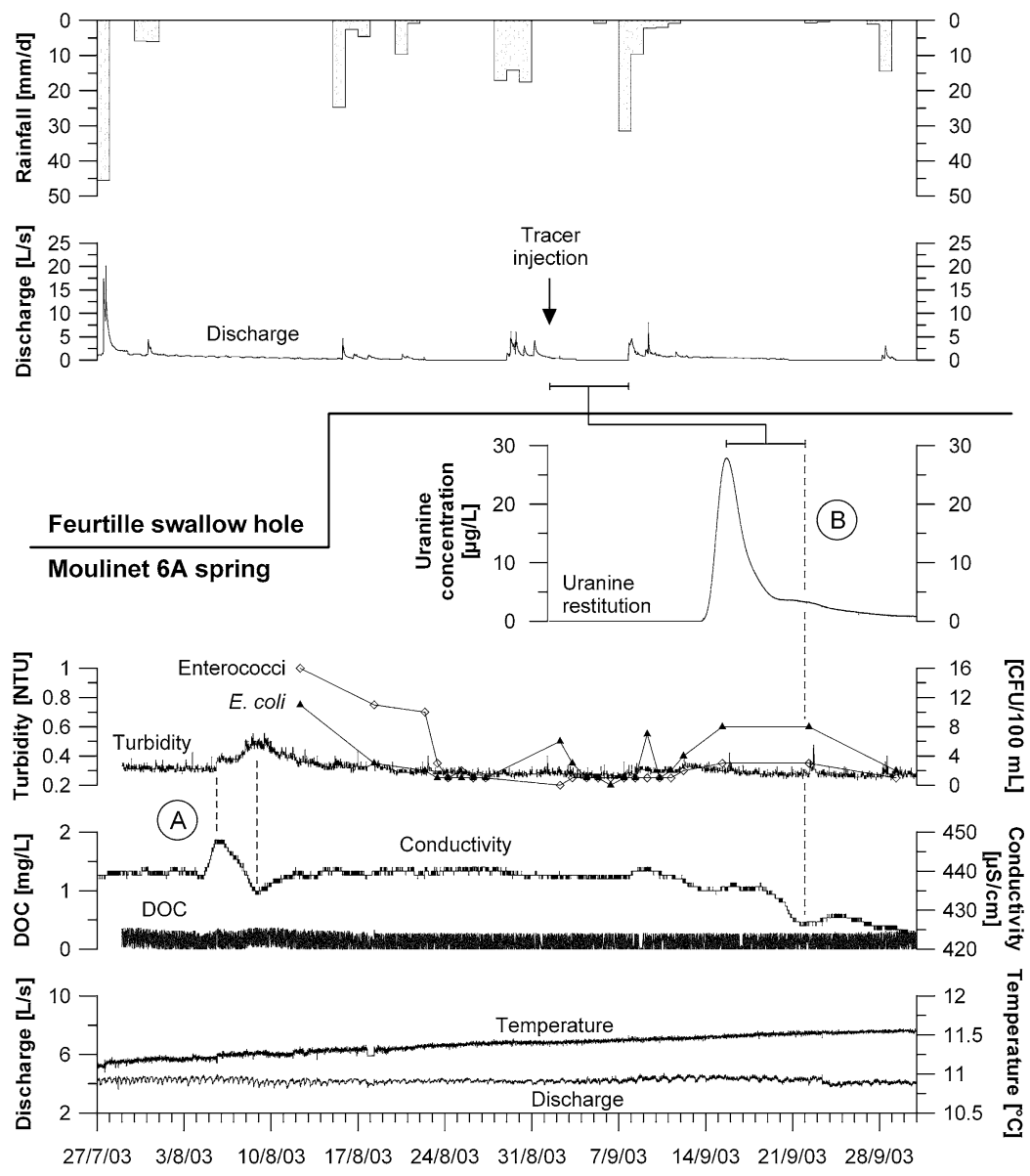

\section{Dynamics during and after heavy rainfall}

During the first nine days of October 2003, it rained every day in the region. The karst aquifer system consequently changed from low-flow to higher flow conditions: The nonpermanent Moulinet springs 7A and 7C-F started to discharge, and all natural parameters that were recorded at spring 6A showed significant dynamics. Three types of signals were observed: pulse-like, step-like and roughly linear trends. The signals were either negative (e.g. negative temperature pulse) or positive (e.g. positive turbidity pulse).

The hydraulic and physicochemical response of spring $6 \mathrm{~A}$ started after four days of rainfall with a step-like increase of discharge, a step-like decrease in temperature and a small turbidity pulse (Fig. 5A). There was no variation of DOC or electrical conductivity, which would have indicated the arrival of freshly infiltrated water from the soil or sinking streams. The observed behaviour can thus be explained by an increasing flow rate of the cold groundwater components, while the flow rate of the deep, thermal component remains largely constant. The small turbidity peak can be explained by remobilisation of sediments inside the karst conduit network due to increasing flow velocities (autochthonous turbidity).

The storm rainfall event on the 7th of October (Yverdon: $21 \mathrm{~mm}$, Baulmes: $48 \mathrm{~mm}$, Auberson: $48 \mathrm{~mm}$ ) caused a sudden step-like increase of the discharge rate, a sharp pri- mary turbidity peak ( $35 \mathrm{NTU}$ ) and a negative temperature pulse at the Moulinet 6A spring (Fig. 5B). At the same time, a small DOC peak and high contents of bacteria were observed, indicating the arrival of freshly infiltrated water from the land surface or soil zone. Because of the short lag between the rainfall and the reaction of the spring, this behaviour can only be explained by the arrival of water from the local recharge area of the spring, i.e. the Mont de Chamblon.

The storm rainfall also caused a significant pulse-like increase of discharge $(26 \mathrm{~L} / \mathrm{s})$, TOC $(220 \mathrm{mg} / \mathrm{l})$ and nitrate (400 mg/l; not shown) at the swallow hole (Fig. 5, above). The continuous measurement of discharge and TOC allows for calculation of the input mass of TOC into the karst aquifers system during this event, about $300 \mathrm{~kg}$. As described above, DOC often makes up about $90 \%$ of the TOC (Batiot 2003; Thurman 1985). The measured TOC mass thus roughly corresponds to $270 \mathrm{~kg}$ DOC.

Several days after the storm rainfall event, during the falling limb of the hydrograph, important secondary variations were observed at spring 6A (Fig. 5C). Three days after the event, DOC and bacteria concentrations started to rise. Five to seven days after the event, $128 \mathrm{E}$. coli, 45 enterococci, 1160 coliforms and 8700 m.a.b. were detected in $100 \mathrm{ml}$ of spring water. The maximal DOC concentration of $1.8 \mathrm{mg} / \mathrm{l}$ was measured on the ninth day. Nitrate shows a similar evolution and reaches a maximum concentration 
Fig. 5 Dynamics of natural parameters during and after heavy rainfall at the Moulinet $6 \mathrm{~A}$ spring (below) and the Feurtille swallow hole (above). The first reactions of the spring were observed after four days of rainfall (A). An important storm rainfall event occurred on the 7 th of October and caused a primary (B) and secondary (C) response of the spring

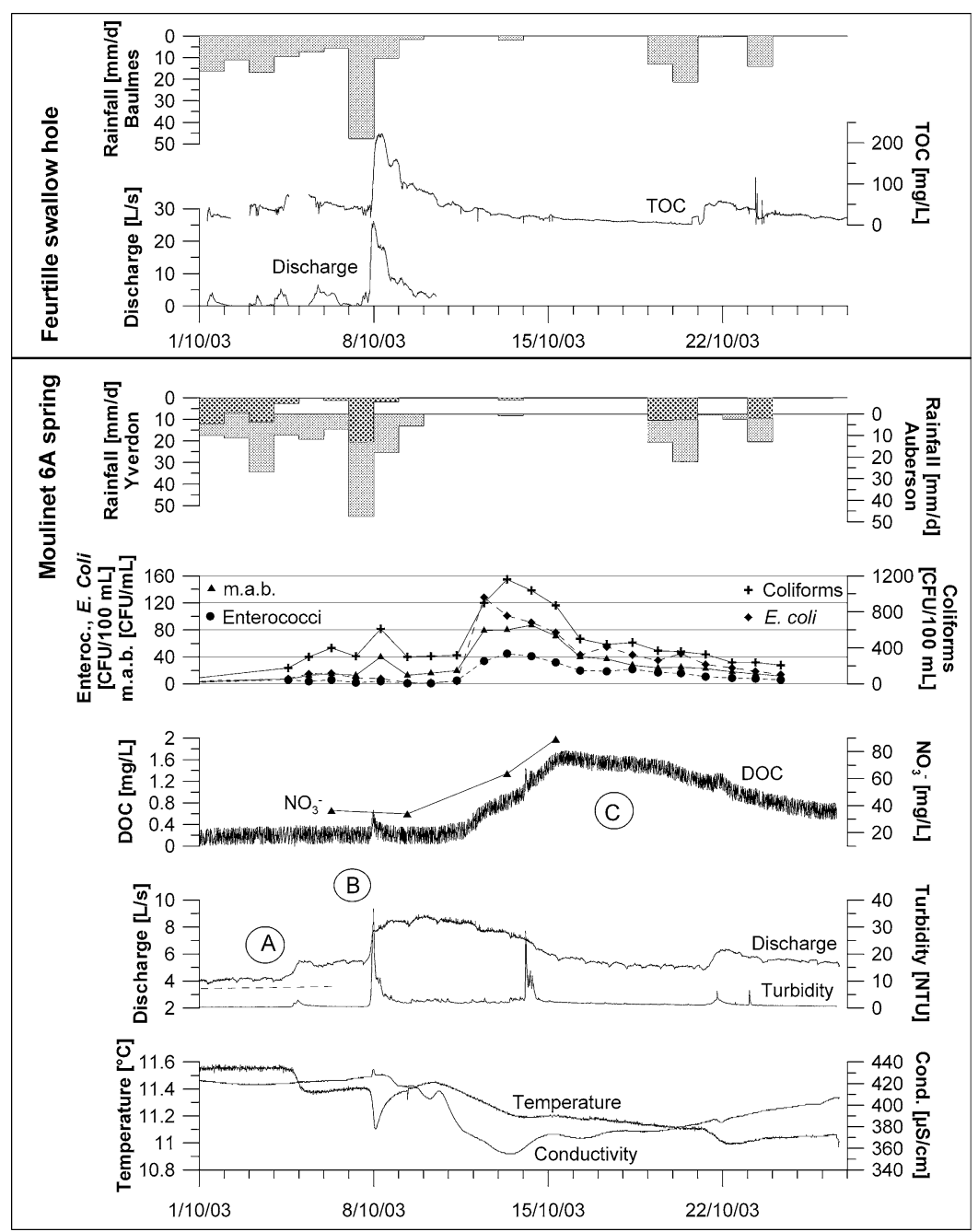

of $80 \mathrm{mg} / \mathrm{l}$. Seven days after the storm rainfall event, a sharp turbidity peak was observed. As this signal occurred during a period of decreasing flow rates, it cannot be explained by remobilisation of sediments inside the conduit network. The observed signal can only be attributed to the infiltration of turbid surface water into the aquifer during the storm rainfall event (allochthonous turbidity). The data also suggest that an important proportion of the bacteria, DOC and nitrate originate from the agricultural surface in the catchment of the swallow hole.

The output of DOC at the Moulinet 6A spring during this event, calculated on the basis of the discharge rate and the DOC concentration, is about $9.5 \mathrm{~kg}$. Given the input mass of $270 \mathrm{~kg}$ at the swallow hole, the DOC recovery rate at spring $6 \mathrm{~A}$ is $3.5 \%$. During the tracer test described, the uranine recovery rate at spring $6 \mathrm{~A}$ was $3.7 \%$.

\section{Application of molecular methods to assess the total bacterial diversity}

\section{Overview}

As described in the introduction, aquifers are increasingly considered as ecosystems, providing habitats for a variety of microorganisms, mainly bacteria (Northup and Lavoie 2001; Simon et al. 2001). However, classical cultivation methods only allow the detection of cultivable bacteria, while the majority of bacteria in oligotrophic groundwater are non-cultivable. New methods from molecular microbial ecology allow characterising the total bacterial diversity in aquifers. At the test site, these methods were applied to water samples taken at the Feurtille swallow hole and the Moulinet 6A and B springs.

\section{Materials and methods}

The water samples were collected in sterile bottles and transported to the laboratory in a cooling box. Using a sterile filtration unit, the water samples were passed through hydrophilic polycarbonate membranes with $0.2 \mu \mathrm{m}$ pore size (Cyclopore, Whatman). The filters were then carefully folded using flamed tweezers, placed into sterile $2.0 \mathrm{ml}$ centrifuge tubes and stored at $-70^{\circ} \mathrm{C}$ until DNA extraction. Genomic DNA was extracted from the filters with the FastDNA Spin Kit (Bio 101, Q-BIOgene) according to the instructions of the manufacturer.

The DNA obtained was sufficiently pure to proceed directly with the PCR (Polymerase Chain Reaction) amplifi- 


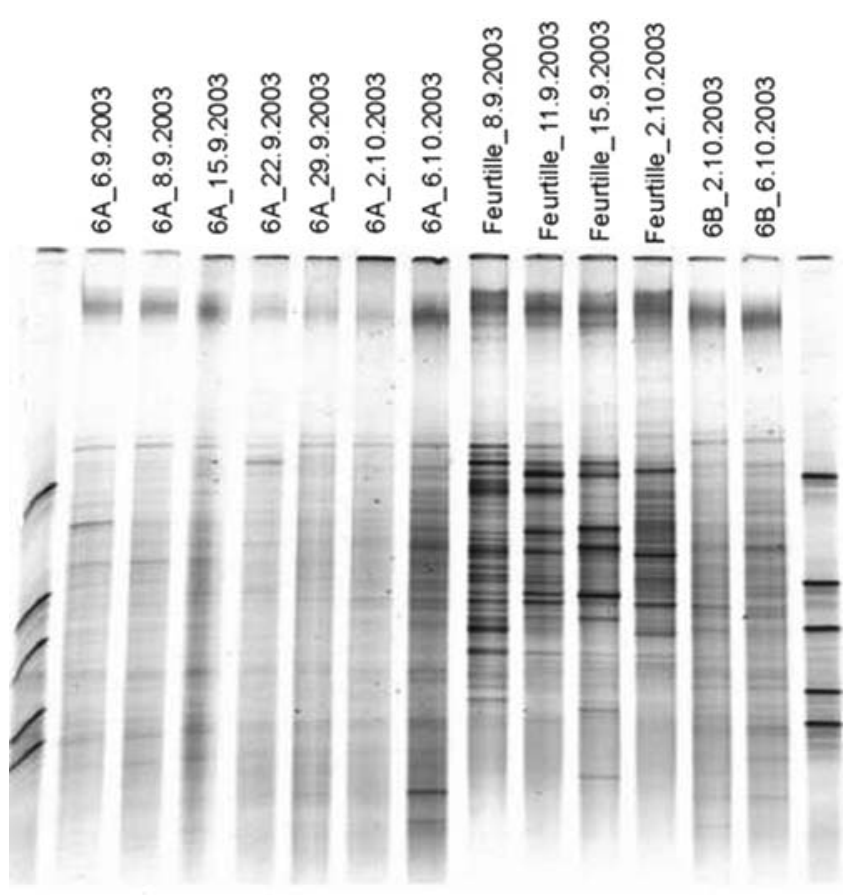

$\begin{array}{lllllllllllllll}1 & 2 & 3 & 4 & 5 & 6 & 7 & 8 & 9 & 10 & 11 & 12 & 13 & 14 & 15\end{array}$

Fig. 6 DGGE fingerprints of the bacterial community at the Feurtille swallow hole (lanes 9-12) and two springs (lanes 2-8: Moulinet 6A; lanes 13-14: Moulinet 6B). Lanes 1 and 15: Standard, a mixture of 16S rDNA fragments amplified by PCR from DNA of five bacterial pure cultures

cation of the $\mathrm{V} 3$ region on the $16 \mathrm{~S}$ rRNA gene. This gene is present in all prokaryotes and its sequence composition holds the information for the identity and phylogenetic relationship of a given bacterium to other microorganisms. PCR was done on a PTC-200 Peltier Thermal Cycler (MJ Research Inc. Mass.) using Taq polymerase (Promega) and the primers 338f with a GC-clamp and 518r (Ovreas et al. 1997; Muyzer 1999). The detailed description of the PCR conditions can be found in Slijepcevic et al. (submitted).

Denaturing Gradient Gel Electrophoresis (DGGE) allows separating the PCR products (DNA fragments) that have identical or nearly identical length but differ in their sequence composition. The separation is based on changes in electrophoretic mobility of the DNA fragments migrating in a polyacrylamide gel containing a linearly increasing concentration of DNA denaturants (formamide and urea). As the DNA fragments are subjected to electrophoresis, partial melting of the double stranded DNA occurs at a denaturant concentration specific for the nucleotide sequence of the DNA and the migration of the fragment is therefore severely retarded (Heuer and Smalla 1997; Theron and Cloete 2000).

Each band in a gel represents in principle one type of bacterium and the intensity of a band is proportional to its relative abundance in the sample. Each lane in a DGE gel is then a 'genetic fingerprint' (Fig. 6) of the microbial community in the sample. A detailed description of the DGGE separation conditions used in this study can be found in Slijepcevic et al. (submitted).

\section{Results}

Figure 6 shows the DGGE analysis of 16S rDNA fragments amplified from DNA extracted from water samples taken at the swallow hole and the springs. About 19 intense bands can be observed in the fingerprint from water samples taken at the Feurtille swallow hole during a rainfall event on the 8th of September, indicating that the bacterial community is dominated by the presence of a few abundant species. The banding pattern changes between the different sampling dates indicating that the microbial community in the draining water is continuously changing. However, the closer the sampling dates, the more similar are the fingerprints.

The bacterial fingerprints from the spring water samples differ from the swallow hole samples. The complex pattern with rather faint bands indicates the presence of bacterial communities that consist of a large number of equally abundant species. Several of the species that characterise the microbial community at the swallow hole cannot be observed in the spring water, i.e. the corresponding bands are not present on the gel. This is also true for the sample from the 22nd of September, which corresponds to the rainfall event at the swallow hole on the 8th of September. Furthermore, the change in the bacterial community at the swallow hole between the 8th and 15th of September is not mirrored in the spring water samples from the 22nd and 29th of September. Possible factors that may explain the disappearance of certain species include the adsorption of bacteria to particles and concomitant sedimentation, the incorporation into biofilms on aquifer walls, grazing by protozoa or die-off without reproduction. Significant dilution of the swallow hole water by less contaminated water from the karst aquifer takes place, but it is unlikely to explain the above observation since it would affect all species equally and hence the dominant bands should still be visible in the fingerprints of the spring water.

\section{Summary and conclusions}

\section{Dynamics and interaction of organic carbon, turbidity and bacterial communities}

The detailed observation of natural parameters at the swallow hole and springs during different hydrologic conditions made it possible to better characterise the dynamics and interaction of organic carbon, turbidity and bacteria in this karst aquifer system.

Turbidity events at karst springs can be classified as primary or secondary, and as allochthonous or autochthonous (Lacroix et al. 2000). Primary turbidity events can be observed during or shortly after a storm rainfall event, together with increasing discharge. Such an event occurred at the Moulinet 6A spring directly after the storm rainfall event of the 7th of October. The secondary turbidity peak arrived seven days later during a period of decreasing discharge and without additional rainfall. High contents of DOC and bacteria were measured at the same time. This secondary turbidity peak clearly originates from the infiltration of turbid water into the swallow hole and can thus be classified as allochthonous turbidity. The two 
turbidity peaks that occurred on the 4-5 and 21-22 October are predominantly autochthonous, as they coincide with increasing discharge rates, while little variations of DOC and bacteria levels were observed. It is interesting to compare in detail the turbidity graph and the evolution of the bacteriological parameters: High turbidity always coincides with high contents of bacteria, but high contents of bacteria do not always coincide with high turbidity. Turbidity peaks are always narrow, while bacteria signals are much wider.

Although some carbonate rocks contain traces of organic matter, the DOC production inside a karst aquifer is negligible. DOC forms in the soil and surface waters by incomplete degradation of dead plant material (Thurman 1985). During recharge periods, it infiltrates into the aquifer, either diffusely through the soil (autogenic recharge) or concentrated via swallow holes (allogenic recharge). In the groundwater, it may be degraded and transformed by microbial activity. DOC in groundwater is thus allochthonous and can be used as a natural time-tracer indicating the arrival of freshly infiltrated water (Batiot et al. 2003). At the Moulinet 6A spring, the DOC concentrations remained constantly low $(0.2 \mathrm{mg} / \mathrm{l})$ during a 10-weeks observation period, while several other parameters showed some variations. Three days after the storm rainfall event of the 7th of October, DOC concentrations started to increase. The contents of faecal indicator bacteria started to increase at the same time. However, the temporal evolution of all bacteriological parameters preceded the evolution of DOC (Fig. 7). The hysteresis loops shown in this figure may reflect differences in transport behaviour of bacteria and DOC inside the aquifer. However, the difference might also be in the catchment of the swallow hole. Bacteria may predominantly be transported via rapid surface runoff at the soil surface, while DOC reflects slower percolation though the soil towards the swallow hole. This
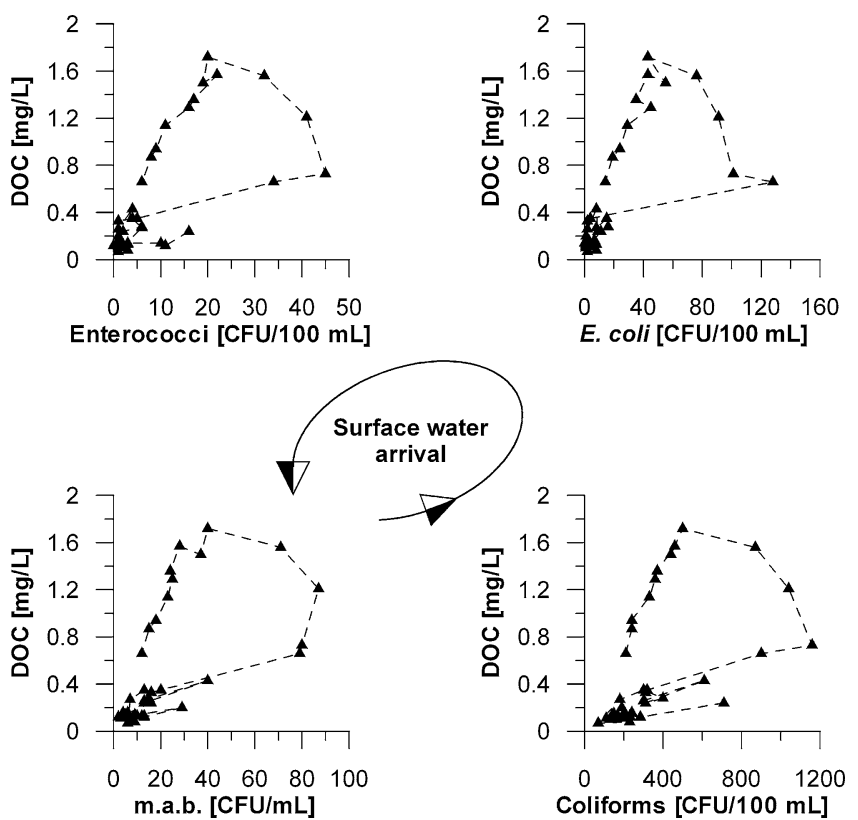

Fig. 7 Correlation between DOC and bacteria at the Moulinet 6A spring during the October event. The graphs show a hysteresis effect, i.e. the temporal evolution of bacteria precedes the evolution of DOC hypothesis can be checked by monitoring bacteria and organic carbon at the swallow hole. In other karst areas, however, bacterial contamination in spring water mainly results from autogenic recharge through the soil (Gunn et al. 1998).

Methods from molecular microbiology made it possible to characterise the bacterial communities in water samples from the swallow hole and the Moulinet springs 6A and B. The bacterial communities at the springs show almost identical genetic fingerprints and seem to be much less variable in time than at the swallow hole. This observation is consistent with the observed dynamics of natural hydrologic, physical and chemical parameters. In this first attempt, the general bacterial diversity and dynamics at the swallow hole and the two corresponding springs were determined during low and high flow conditions. Further analyses, including sequencing of dominant bands, will facilitate the identification of the key components of the subsurface microbial communities the drawing of conclusions about their potential ecological role. The application of molecular methods will also allow more to be learned about selective retention or elimination of specific bacterial groups in a karst aquifer, and may make it possible to use the 'genetic fingerprints' of microbial communities as a natural tracer.

\section{Consequences for groundwater protection and spring water quality monitoring}

The results show that the stream sinking into the Feurtille swallow hole does not contribute significantly to the discharge rate of the Moulinet and Cossaux springs. During the tracer test, the total discharge of the springs was $62 \mathrm{~L} / \mathrm{s}$ while the flow rate at the swallow hole was only $1 \mathrm{~L} / \mathrm{s}$. Nevertheless, the swallow hole poses a threat to spring water quality. Extremely high contents of faecal indicator bacteria $(419000$ coliforms in $100 \mathrm{ml})$, nitrate $(400 \mathrm{mg} / \mathrm{l})$, TOC $(220 \mathrm{mg} / \mathrm{l})$ and turbidity (350 NTU) were measured at the swallow hole. The tracer test showed that these contaminants may reach the Cossaux and Moulinet springs after 11 and 12 days during low-flow conditions. Previous tracer tests during higher flow conditions gave shorter transit times, about two days. The tracer test also showed that an important part of the contaminants that sink into the swallow hole reappear at the springs.

In order to assure good spring water quality, it is thus essential to improve the situation at the swallow hole. There are three possibilities to do so: (1) improve the protection zones in the surface catchment of the swallow hole, i.e. restrict agricultural land use; (2) close the swallow hole and divert the sinking stream into a nearby stream; (3) install measuring devices at the swallow hole as an early warning system for spring water contamination.

The study also showed that turbidity alone is not a reliable indicator for the presence of faecal bacteria in the Moulinet springs. High turbidity always indicates high contents of bacteria, but important bacteriological contamination can also be observed in periods with low turbidity. DOC appears to be an interesting indicator parameter: An increase in DOC coincides with a dramatic increase in bacteria and nitrate. However, this parameter is not sensitive enough 
to indicate low-level microbial contamination events. Furthermore, the temporal evolution of the bacteria contents precedes the evolution of DOC, which limits the applicability of DOC as an early-warning parameter for microbial contamination.

Acknowledgements The Energy Service of Yverdon (SEY) funded this study. We are grateful to Claude-Olivier Pelet, Olivier Flückiger and Pierre Siegrist (SEY) for the good cooperation. We thank Dr. Pierre-André Schnegg for his outstanding field fluorometers, Mari-Eve Farine, Vanessa Di Marzo and Ana Slijepceviv for laboratory work, François Bourret for technical support, and our trainee Xavier Drogue for testing the measuring devices. We thank Pierre Gutzwiler (SIGRIST Photometer AG) for the good cooperation, and MeteoSwiss for the precipitation data. We thank the reviewers for their valuable comments, and Dr. David Drew for language corrections. This study was carried out in order to prepare the BEKARST project, subproject KARSTDYN (dynamics of microbial communities, organic carbon and particles in karst groundwater), which is funded by the Swiss National Science Foundation since October 2004 (Project No. 200020-105427)

\section{References}

Alberic P, Lepiller M (1998) Oxidation of organic matter in a karstic hydrologic unit supplied through stream sinks (Loiret, France). Water Res 32(7):2051-2064

Amraoui F, Razack M, Bouchaou L (2003) Turbidity dynamics in karstic systems. Example of Ribaa and Bittit springs in the Middle Atlas (Morocco). Hydrological Sciences Journal-Journal des Sci Hydrologiques 48(6):971-984

Atkinson TC, Smith DI, Lavis JJ, Whitaker RJ (1973) Experiments in tracing underground waters in limestones. J Hydrol 19(4):323-349

Atteia O (1998) Evolution of size distributions of natural particles during aggregation: modelling versus field results. Coll Surf A -Physicochem Engin Asp 139(2):171-188

Atteia O, Kozel R (1997) Particle size distributions in waters from a karstic aquifer: from particles to colloids. J Hydrol 201(1-4): $102-119$

Auckenthaler A, Huggenberger P (2003) Pathogene Mikroorganismen im Grund- und Trinkwasser. TransportNachweismethoden-Wassermanagement (Pathogenic microorganisms in groundwater and drinking water. Transport, analytical methods and water management): 196 p.; Birkhäuser

Auckenthaler A, Raso G, Huggenberger P (2002) Particle transport in a karst aquifer: natural and artificial tracer experiments with bacteria, bacteriophages and microspheres. Water Sci Technol 46(3):131-138

Batiot C (2003) Etude expérimentale du cycle du carbone en régions karstiques (Experimental study of the carbon cycle in karst areas). PhD, University of Avignon, France

Batiot C, Emblanch C, Blavoux B (2003) Total Organic Carbon (TOC) and magnesium $\left(\mathrm{Mg}^{2+}\right)$ : two complementary tracers of residence time in karstic systems. Comptes Rendus Geosci 335(2):205-214

Bouchaou L, Mangin A, Chauve P (2002) Turbidity mechanism of water from a karstic spring: example of the Ain Asserdoune spring (Beni Mellal Atlas, Morocco). J Hydrol 265(1-4):34-42

Boyer DG, Pasquarell GC (1999) Agricultural land use impacts on bacterial water quality in a karst groundwater aquifer. J Am Water Resou Assoc 35(2):291-300

Byrd JJ, Xu HS, Colwell RR (1991) Viable but non-culturable bacteria in drinking water. Appl Environ Microbiol 57:875-878

Chapelle FH (2001) Ground-water microbiology and geochemistry. John Wiley \& Sons, New York

Cornaton F, Perrochet P (2002). Analytical 1D dual-porosity equivalent solutions to $3 \mathrm{D}$ discrete single-continuum models. Application to karstic spring hydrograph modelling. J Hydrolo 262(1-4):165-176
Danielopol DL, Griebler C, Gunatilaka A, Notenboom J (2003) Present state and future prospects for groundwater ecosys-tems. Envir Conserv 30(2):104-130

Drew D, Hötzl H (eds) (1999) Karst Hydrogeology and Human Activities. Impacts, Consequences and Implications-International Contributions to hydrogeology, 20. Balkema, Rotterdam

Emblanch C, Blavoux B, Puig JM, Mudry J (1998) Dissolved organic carbon of infiltration within the autogenic karst hydrosystem. Geophys Res Lett 25(9):1459-1462

Ford D, Williams DW (1989) Karst geomorphology and hydrology. Unwin Hyman, Boston

Goldscheider N (2002) Hydrogeology and Vulnerability of Karst Systems. Examples from the Northern Alps and Swabian Alb. PhD, University of Karlsruhe. Schr Angew Geol Karlsruhe 68:1-236

Gunn J, Tranter J, Perkins J, Hunter C (1998) Sanitary bacterial dynamics in a mixed karst aquifer. In: Leibundgut $\mathrm{C}$, Gunn J, Dassargues A (eds) Karst Hydrology, vol 247, IAHS Publication, pp 61-70

GSchV (1998) Water Protection Ordinance, GSchV, SR 814.201, Swiss Federal Law, Bern

Heuer H, Smalla K (1997) Application of denaturing gradient gel electrophoresis and temperature gradient gel electrophoresis for studying soil microbial communities. In: van Elsas JD, Trevors JT, Wellington EMH (eds) Modern Soil Microbiology. Marcel Dekker, New York, pp 353-374

Jordi HA (1994) Atlas géologique de la Suisse 1:25000, feuille 1203: Yverdon-les-Bains (Swiss geological atlas 1:25000, sheet 1203: Yverdon-les-Bains). Service hydrologique et géologique national, Ittigen

Käss W (1998) Tracing technique in geohydrology. Balkema, Rotterdam

Katz BG, Catches JS, Bullen TD, Michel RL (1998) Changes in the isotopic and chemical composition of ground water resulting from a recharge pulse from a sinking stream. J Hydrol 211(1-4): $178-207$

Lacroix M, Rodet J, Wang HQ, Masséi N, Dupont JP (2000) Origine des matières en suspension dans un système aquifère karstique: apports de la microgranulométrie (Origin of suspended matter in a karst aquifer system: contribution of microgranulometry). C R Acad Sci Paris, Sciences de la Terre et des Planètes 330(2000):347-354

Mahler BJ, Personne JC, Lods GF, Drogue C (2000) Transport of free and particulate-associated bacteria in karst. J Hydrol 238(3-4): 179-193

Massei N, Wang H, Dupont J, Rodet J, Laignel B (2003) Assessment of direct transfer and resuspension of particles during turbid floods at a karstic spring. J Hydrol 275(1-2):109-121

Mikell AT, Smith CL, Richardson JC (1996) Evaluation of media and techniques to enumerate heterotrophic microbes from karst and sand aquifer springs. Microb Ecol 31(2):115-124

Muralt R (1999) Processus hydrogéologiques et hydrochimiques dans les circulations profondes des calcaires du Malm de l'arc jurassien (Hydrogeological and hydrochemical processes in the circulation system in the Malm limestones of the Jurassic belt). $\mathrm{PhD}$, University of Neuchâtel, Switzerland

Muralt R, Vuataz FD, Schonborn G, Sommaruga A, Jenny J (1997) Integration of hydrochemical, geological and geophysical methods for the exploration of a new thermal water resource. Case of Yverdon-les-Bains, foot of the Jura range. Eclogae Geologicae Helvetiae 90(2):179-197

Muyzer G (1999) DGGE/TGGE a method for identifying genes from natural ecosystems. Curr Opin Microbiol 2(3):317-322

Nebbache S, Loquet M, Vinceslas-Akpa M, Feeny V (1997) Turbidity and microorganisms in a karst spring. Europ J Soil Biol 33(2):89-103

Northup DE, Lavoie KH (2001) Geomicrobiology of caves: A review. Geomicrobiol J 18(3):199-222

Ovreas L, Forney L, Daae FL, Torsvik V (1997) Distribution of bacterioplankton in meromictic Lake Saelenvannet, as determined by denaturing gradient gel electrophoresis of PCR-amplified gene fragments coding for 16S rRNA. Appl and Envir Microbiol 63(9):3367-3373 
Personne JC, Poty F, Vaute L, Drogue C (1998) Survival, transport and dissemination of Escherichia coli and enterococci in a fissured environment. Study of a flood in a karstic aquifer. J Appl Microbiol 84(3):431-438

Ryan M, Meiman J (1996) An examination of short-term variations in water quality at a karst spring in Kentucky. Groundwater 34(1):23-30

Schnegg PA, Costa R (2003) Tracer tests made easier with field fluorometers. Technical note. Bull Hydrogeol 20 89-91

Simon KS, Gibert J, Petitot P, Laurent R (2001) Spatial and temporal patterns of bacterial density and metabolic activity in a karst aquifer. Archiv für Hydrobiologie 151(1):67-82

Slijepcevic A, Rossi P, Aragno M, Zopfi J. Relationship between environmental factors and community structure of bacterioplankton as revealed by ribosomal 16S DNA and RNA DGGE fingerprints in a holomictic, eutrophic lake. FEMS Microbiol. Ecol. (submitted)
Sommaruga A (1996) Geology of the central Jura and the Molasse Basin: new insight into an evaporite-based foreland fold and thrust belt. PhD, University of Neuchâtel, Switzerland

Sommaruga A (1999) Decollement tectonics in the Jura foreland foldand-thrust belt. Marine and Petroleum Geology 16(2):111-134

Szewzyk U, Szewzyk R, Manz W, Schleiffer KH (2000) Microbiological safety of drinking water. Annu Rev Microbiol 54:81127

Theron J, Cloete TE (2000) Molecular techniques for determining microbial diversity and community structure in natural environments. Crit Rev Microbiol 26(1):37-57

Thurman E (1985) Organic chemistry of natural waters. Nijhoff, Junk, Dordrecht

Zwahlen F (ed) (2004) Vulnerability and risk mapping for the protection of carbonate (karst) aquifers, final report (COST action 620). European Commission, Brussels 